\title{
The Challenge of Legal Marital Law Implementation in Local Context of Indonesia: A Case Study on Marriage Practice in Madura
}

\author{
Jamilah \\ Universitas Islam Negeri Maulana Malik Ibrahim Malang \\ zhenit79@yahoo.com
}

\begin{abstract}
Marriage serves many purposes for either men or women particularly muslim community. For muslims in rural area, for instance, marriage is an important phase of their life. It can be perceived as natural cycle of life by people. For many, it is also a need to preserve their existences in society. For individuals, marriage is a variously economic ticket, a socializing influence, a form of child care, a means of escape from social constrains and the locus of many other hopes and desires. What is interesting from the point of viewing marriage is the different purposes which marriage is expected to serve man and women in various angles. This article will outline the main issue of legal marital law implementation in local context in Madura which focuses two practices; local marriage procedure and early marriage practice that are mostly different from what have been regulated by the government.
\end{abstract}

Keywords: marriage; Madura; legal marital law; local tradition

\section{Introduction}

First of all, it must, of course, be stated that Islam originated in the Arabian Peninsula and from there it spreads all over the world - Asia, Africa, the West. Aside from the myriad of questions about the advent of the Islamization process in Southeast Asia (from the end of the 13th century), Islam in Indonesia is therefore 
originated from the Middle East, and in various Indonesian Islamic literature sources, persons and events from the early Islamic history, thus taking place in the Middle East, play a role. In local area, usually the emphasis on marriage for women and men has been on moral and social as well as, to some extent, outcomes, both for themselves and for society. As the irony of the fact of the importance of marriage, particular aspect in marriage such as age is mostly ignored by society and by women themselves although it is closely related to the issue of women's independency related to decide marriage at particular age and to choose the spouse. The line of the debate is on the prerogative of women in deciding the age that they want to get married and the person they want to marry with has no significant relationship with legal marital law which has been regulated by the government. ${ }^{1}$ However, not all the cases of early marriage are the problems of loosing personal prerogative as it can be free and personal choice. Another debatable issue which will be outlined in this article is that the challenge of legal marital law to be implemented in a local context in terms of age. To some extent, marriage has been regulated formally by the government to maintain the main aim of marriage. Nonetheless, it cannot be implemented fully in a local context due to some considerations such as economy, education, social as well as religious understanding.

\section{Madura Social Structure}

It is worth to note that Madura is identified with Islam and Ulama although not all the inhabitants are Muslims. These two elements are closely associated with the cultural identity of the society. ${ }^{2}$ Moreover, Madurese society is acknowledged as a santri society. Another consequence is that ulamas have a special position in social hierarchies. First, ulamas in Madura play an important role and have an authority in religious, social, and to some extent, political life of Madurese people. They are considered as figures to be respected and to be obeyed when they give advice. In the context of social life, Madurese people respect and tend to consult with the ulamas rather than the government. They have a close relationship with ordinary people. ${ }^{3}$

\footnotetext{
${ }^{1}$ John R. Bowen, Islam, Law, and Equality in Indonesia: An Anthropology of Public Reasoning (Cambridge: Cambridge University Press, 2003).

2 Andang Subaharianto, Tantangan Industrialisasi Madura (Malang: Bayumedia Publishing, 2004).

3 BPS Bangkalan, Bangkalan in Figures 2003 (Bangkalan: BPS kabupaten Bangkalan, 2004).
} 
There are two significant reasons for why this group of religious leaders possesses a specific position in their societies. First, Madurese people are identified with a strong Islamic identity which is rooted in history. Scholars (e.g. De graaf ${ }^{4}$ and Pigeaud ${ }^{5}$ ) state that the Islamization process of local inhabitants started intensively in the 16th century when local kingdoms embraced Islam. In line with the intensity of trade among other areas in Java, the islamization process in Madura developed significantly. As a result, important regions which had the potential for trade development in Madura, like Sumenep, grew important Islamic region among other regions.

Second, despite the historical record, ecological condition (tegal) and the structure of inhabitants' settlement becomes another factor in explaining the specific social position of religious leaders. Those two factors lead to the emergence of social organization that is based on religion and ulama's authority. Here, ulamas play their significant role as the solidarity adhesive, ritual religious activity motivator, and creator of religious collectivity sentiment, social elements or kinship groups spreading in different places due to the structure of settlement. ${ }^{6}$

As has been shown, in Madurese social structure there is also an ordinary people group in the lowest level. It is worth noting that they perceive the position of kyais conservatively. As long as their attitude and actions can be accepted socially, they are still respected by people. For instance, the practitioners of polygamy usually are coming from this prestigious group. None of the people comment significantly on this matter. It means that they still acknowledge that kyais come from prestigious people whom they must respect morally. Therefore, there is a vertical moral relationship and interaction between religious leaders and ordinary people. To some cases, they may marry a woman in the very young age.

\section{Unregistered Marriage Practice in Local Madura}

Marriage is basically human beings' need since it is related to law, society and religious affairs. Ideally, marriage must be under the protection of government and must be in accordance with the religion as well as the beliefs of the people. As an example of a highly plural society, Indonesia is one of many countries which have a cultural diverse approach to marriage process. In Madurese society,

\footnotetext{
${ }^{4}$ Th Pigeaud and H. J. de Graaf, "Islamic States in Java," I500-1700', Verhandelingen van Het Koninklijk Instituut Voor Taal, Land-En Volkenkunde 70 (1976).

${ }^{5}$ Theodore Gauthier Pigeaud, Islamic States in Java 1500-1700 (Leiden: Brill, 1976).

${ }^{6}$ Stephen Ellingson and M. Christian Green, Religion and Sexuality in Cross-Cultural Perspective (New York: Routledge, 2014).
} 
particularly in Tlokoh village (where this study is conducted), the marriage process is not significantly different from other areas. Practically speaking, however, it is noteworthy to emphasize that most of marriage ceremony in this village is conducted based on religious legitimacy but seldom under the protection of the legal law as mandated by the government. A man and a woman agree to get married by themselves. However, most of them get married due to parent's instruction or pressure from individuals in the village such as kyais, ibunyai and son of kyais (lora). A daughter or a son may not refuse the advice of the aforementioned people as they are respected and are believed to have solutions for any problems in society.

However, the main authority on marriage, in respect to women, basically is the parents. First, the offer for the marriage comes to the parents. The man will visit the woman's house to ask the parents whether the daughter is already engaged to another man. Usually during the visit, the woman is asked to visit a while in order for the man to see her. After seeing her, if the man agrees with to take her as his wife, he will propose to the daughter's parents. Second, an agreement will be decided between the woman's family and the husband. In this case, the daughter's opinion is not taken into main consideration. The authority of parents plays the most important role in the acceptance of the offer as well as to refuse it. ${ }^{?}$

Basically, there are several formal steps that a marriage should pass through to be accepted. Nonetheless, people commonly do not practice the accomplishment of marriage procedure based on the law of marriage. After two families agree to build a family relationship through marriage, parents will inform the head of the village (klebun). Then, the klebun will manage the marriage officially (formally) as well as culturally. The klebun will bring the affair to the local government in Sub-district. Then, the officers will inform the KUA. However, as suggested by the officer in the sub-district, it is seldom that klebun will register the marriage of their people to the KUA for particular reasons such as budget concerns to make the formal letter of the marriage. The Klebun usually only informs the officers of the sub-district government. Apart from the formal aspects of marriage, it is difficult to have the marriage legalized by KUA. To be registered with the PPN (Pegawai Pencatatan Pernikahan/Formal Officer for Marriage Registration) at KUA depends mostly on financial situation of those who want to get married. If they have enough money to pay for the registration and for the

\footnotetext{
${ }^{7}$ Sri Mulyati, Relasi Suami Istri Dalam Islam (Jakarta: PSW UIN Jakarta, 2004).
} 
formal letter for marriage (buku nikah) from KUA, then the klebun will try to register the marriage. By contrast, if they cannot afford it, they pay a certain amount of money to the klebun so-called breget. In subsequent years, for instance, due to particular circumstances and reasons such as working abroad a couple (whether husband or wife) need to have the formal letter from KUA, they can bring this problem firstly to klebun. They must pay the klebun in order for him to register the marriage at KUA and get the letter.

Back to the process of marriage, its second stage is deciding the day of marriage. Usually it is conducted at the bride's house or at another place such as at a mosque or musholla (small mosque) of which all the people agreed. The marriage ceremony is usually led by the local kyais or lora. The ceremony is also attended by the families of the groom as well as the bride, friends, associates, modin (the assistant of KUA officer) and klebun. Interestingly, the ceremony for the first son in the family will be treated differently from the following children. The ceremony will be lasting into the night or for many days. As a matter of fact, sometimes the parents will go into debt to pay for the party. Nevertheless, this is not always the case. It means that, at certain occasion there will be no party as their main concern is the marriage ceremony (marriage contract). During the process of marriage ceremony, like the village secretary and the treasurer, the role of modin is not significant. His existence is formal but not functional.

Until recently, it has been a common phenomenon that in Tlokoh village marriage is rarely registered formally at KUA. In Tlokoh, for instance, in 2004 (for the first eight months) there were 2 registered marriages for each month. Only a few couples registered their marriages in the following months (I to 4 couples). KUA officers admit that the total number of marriages is greater than those registered with the KUA.

As the cases of marriage illustrated in this village, klebun as the head of the village stated that marriage will be allowed although it cannot fulfill the requirements of the formal law as requiring registration with KUA. For instance, if the administrative fee cannot be afforded by the couple or the bride is under the regulated age of marriage, the ceremony is still allowed to be conducted. To quote the Klebun's statement "rather than a young couple stay together without the contract of marriage or they will run away, I had better allow them to get married although they cannot fulfill the formal requirement as regulated by the government". This statement demonstrates only once can get married in this village. However, it is also a dilemma for the local government of the village. 
The problem of registering marriage formally affects the process of divorce in Tlokoh. Divorce in this village is relatively easy. It can be said that divorce is not a big problem for the people. For those who have not registered their marriage to KUA, to break the family relationship is quite easy. At that point, a husband can state to the wife that he wants to divorce her. He should make a letter informing the klebun that his wife is free from the responsibility of being his wife. The husband should take his ex-wife to her parents' house to declare that he is returning his wife to their home.

The practice of easy divorce can be seen also among the kyais and their sons (loras). They easily divorce their wives and easily to get married for a second time. Moreover, the belief of ordinary people to respect this social group may contribute to marriage and divorce affairs within the society. Until this research is conducted, easy marriage and easy divorce are still practiced among these prestigious people. However, this is not always the case that all prestigious people practice this sort of divorce since ordinary people also practice it.

Finally, when a divorce is decided, they prefer not to bring the divorce to the court of religious affairs (Pengadilan agama). According to them, the problem will be more complicated in that institution as opposed to the local government of the village (klebun). Moreover, informing pengadilan Agama will cost money that they probably cannot afford. Having no formal letter fro the very beginning of marriage is also makes the divorce easier. People just need religious justification by implementing syariah law on divorce by stating talak to the wife.

\section{Early Marriage Practice in Local Madura}

As Susan Blackburn suggested that the age at which it is appropriate for girls to marry has been a contentious matter in many countries. ${ }^{8}$ Furthermore, she pointed out that for certain societies, marriage is considered as family's prerogative. It brings up the age of marriage to be quite young. Children in this case are rarely to be consulted about marriage and they seldom propose their own will. Moreover, the marriageable age based on the adulthood qualities for daughters to be a wife and a mother is usually ignored by people in general and particularly by the parents. In fact, if the qualities are put into main consideration the marriage could run stable. Furthermore, divorce and its undesirable impacts are probably can be avoided. Then, the next question is that should girls or

${ }^{8}$ Susan Blackburn, Women and the State in Modern Indonesia (Cambridge University Press, 2004), 57. 
daughters are allowed to choose their husbands by themselves. The standard age which is suitable for getting marriage is another main question. The aim of proposing these two inquiries is to let the girls know all the consequences of marriage. For instance, girls should know the result of getting marriage before eighteen such as how quickly their body will deteriorate after giving a birth.

Consideration of girls to get marriage earlier is differently argued by people. For many, if the girl has her first menstruation and reached the age of fifteen, she is old enough to marry. A story of Don Juan reveals the way of Minangkabaus people perceive marriageable age for their daughters. This story tells:

It is right for parents to choose the husband. And among us (matrilineal) Minangkabaus, the rights of male elders must be consulted. If you leave it to a girl, she may be tricked into marriage by a womanizer or misled by men who deceived girls as we read about in Europe. ${ }^{9}$

Strictly speaking, early marriage in Tlokoh is commonly practiced and is differently perceived by people in this village. On the one hand, marriage at very early age may generate undesirable impact on the children particularly on women as wives. Many possible undesirable impacts are proposed by women in Tlokoh regarding the age of marriage and the prerogative of marriage. Many (e.g. Sittiyeh, early marriage practitioner) pointed out that the practice of early marriage is, to some extent, harmful for women.

In addition, other respondents (of this study) revealed the same line of thought that early marriage is common but less desirable for the wife. For instance, a primary school teacher in this village suggested that to get married at the very early age distorts the girls' freedom to express what they want including their own plan for the future. The parents' worry plays a role in supporting early marriage in rural area as well as in Tlokoh.

Interestingly, as suggested by later research conducted by G. W. Jones in 2001 in Madura which reveals the minimum age of marriage that is still low. ${ }^{10}$ This research explains the way of the Madurese views marriage, that for them the important thing is to follow their own version of Islamic law. In addition,

\footnotetext{
${ }^{9}$ Ibid., 60.

${ }^{10}$ Gavin W. Jones, "Which Indonesian Women Marry Youngest, and Why?," Journal of Southeast Asian Studies 32, no. 1 (2001): 67-78.
} 
anecdotal evidence demonstrated a special dispensation of marriage age. Some parents usually collude with local officials in disguising a child marriage. This "negotiation" usually occurs due to a marriage entailing a bride and is below the age of sixteen not permitted officially. As a result, the recorder is often incorrect. In addition, this may be practiced due to certain circumstances such as girls who need to be married off quickly; however, cultural attitudes are also still important: particularly in strong Islamic rural areas many people consider it desirable that girls be married as early as possible. ${ }^{11}$

Additionally, previous research in the Bangkalan regency of Madura in 1977 suggested the ineffectiveness of the 1974 Marital Law on this island which deals with a minimum age for marriage. Marriage at an earlier age was remained widespread among girls below twenty in one of sub-districts in the Bangkalan regency. There was an identifiable trend toward early marriage. This research also reveals that the marriage of girls under sixteen remained commonplace and was widely accepted within the community. ${ }^{12}$

Like in Tlokoh, early marriage among teenagers is a widely accepted. The teenagers, especially women, who have graduated from elementary school (SD) are considered or might be considered as capable to get married. The previous observation confirmed the earlier evident that a far greater percentage of girls marry before twenty. Most of the people in this village marry between the age of 13- 16 years old for the women. Meanwhile, the men usually are 16 or 17 years old when they get married. During this research, there was a young couple who had the formal letter from KUA while they got married when the woman was 15 and the man was 17 .

Much has been argued about the tradition of early marriage in Tlokoh, including discussion among the women themselves. Women saw marriage at a very early as a benefit and for the social order. There were a number of reasons for this acceptance. According to those who agreed with the tradition of early marriage, it was good for women socially and economically. It seems that Tlokoh women believe that early marriage can be tolerated due to its positive aspects that can prevent youngsters from undesirable behavior, free sex and uncontrolled social interaction. By choosing husband for the daughters, parents are released from the responsibility of protecting the daughters from bad things. Moreover,

\footnotetext{
${ }^{11}$ Robert Orr Whyte and Pauline Whyte, The Women of Rural Asia (USA: Routledge, 2020).

${ }^{12}$ Sanapiah Faisal, Format-Format Penelitian Sosial (Jakarta: PT Raja Grafindo Persada, 2001).
} 


\section{Jamilah}

this is also for those girls who have no particular activities such as working or studying.

Social order is another point to let the children marry earlier. What is meant by social consideration is the social construction of what activity is less accepted in this village. It is considered a taboo if a single woman walks around the village without any clear needs. In most women's view, it is better if women with no exact activities get married earlier in Madura particularly in rural area like Tlokoh. It will create social problems if they let single women do such activities. People, men and women, will make it as a social issue that will probably make them discuss the girls' attitude to their parents or their relatives.

The logic of practicing early marriage as one good way to maintain social order also explains why parents prefer their daughters marry earlier. An informant from local government revealed the data of particular aspect of early marriage in Madurese rural area such as in the village. He summarized:

Parents are usually happy when a man asks the daughter to be his wife. There are several reasons which may contribute in this case. First, to have son in-law earlier is family's pride. It is a pride for parents when there is an offering for marriage for their daughters. As informed by an informant from local government office in Kokop sub-district that early marriage is part of parents' pride Second, the common range for daughters to get married around 11 to 12 years old. Parents may feel worried when the daughters have not gotten married by the time they are 16 . There is a perception that husbands are difficult to find. However, there is also different perception on the daughters who remained unmarried. For some parents, it can be a destiny on the one hand. It can be also a shameful condition, on the other.

The most interesting argument and forthright views are expressed by two women in Tlokoh (Ainy and Hajar). Hajar made a strong argument for women to accept the practice of early marriage and the authority of parents to choose a husband for them. In her view, it is essential to marry earlier for women in Madura for their future life. Women need to learn to realize that they require a partner in their life because it is inescapable fact that the ideas of women are men's partners in many respects.

The focus here is on the fear of finding a husband not merely finding the right person as a life partner. This personal fear of not having a husband under 
lays the apprehension about refusing an offer of marriage. It will be bad luck for women in the future. In addition, the community will question a woman who refuses a man. They may think that this woman is too selective or have standards improper for a rural area. Woman can be struck down by a calamity by this. For women, marriage is a rite that women should pass through in their life. One aspect of life is to find your soul mate as a partner in life through marriage. If a man comes to propose marriage, there is no reason for woman to refuse as long as he is morally and socially is accepted by people.

A recent case of early marriage occurred in this village of which a twelveyear old girl got married to a boy of the same age. The parents thought their daughter had a special relationship with the boy. When the boy made the first visit, the girl's parents asked him to marry the girl. Interestingly, the boy agreed as well as his parents. Then, the marriage occurred. From the girl's family, parents felt that they had fulfilled their responsibility to protect their daughter's from immoral attitude and to find a husband for her. ${ }^{13}$

For such women in Tlokoh, early marriage had an almost personally revelatory impact and bonded them to the new experience. It was the marriage that protects them from negative impacts of free social interaction with men. It was also early marriage which gives them economical as well as social protection. Therefore, for most Tlokoh women be or resist the practice of early marriage as women may experience the positive aspects of it. However, it does not mean that they do not consider the negative aspect of early marriage is one way to protect women socially and economically.

\section{Conclusion}

Above all the issues, marriage in a local norm, to some extent, ignores women's independency to regulate their marriage in particular aspects. Therefore, a mutual consent of women becomes critical in marriage although women "sincerely" abandoned her rights to be represented by their male guardians (walis) in marriage. Women should be ensured their freedom in such situations on the concept of consultation as the basic principle of marriage since women must be acknowledged their personal and basic rights to be independent to make decision in their life. In closing it may be safely argued that marriage is a media of which gender is respected and equal rights (men and women) are admitted by social and

${ }^{13}$ Mayling Oey-Gardiner and Carla Bianpoen, Indonesian Women: The Journey Continues (Canberra: Pandanus Books, 2000). 


\section{Jamilah}

religious framework. As all such attempts to describe the independency of women in relation with marriage, further research should be conducted.

\section{References}

Blackburn, Susan. Women and the State in Modern Indonesia, UK: Cambridge University Press, 2004

Bowen, John R. Islam, Law and Equality in Indonesia, Cambridge: Cambridge University Press, 2003

BPS Bangkalan. Bangkalan in Figures 2003, Bangkalan: BPS kabupaten Bangkalan, 2004

Ellington, Stephen and M. Christian Green. Religion and Sexuality in Cross Cultural Perspectives, New York: Routhledge, 2002

Faisal, Sanapiah. Format-Format Penelitian Sosial, Jakarta: PT Raja Grafindo Persada, 2001

Jones, Gavin W. "Which Indonesian Women Marry Youngest, and Why?" Journal of Southeast Asian Studies 32, no. 1 (2001): 67-78.

Mayling, Oey, et all. Indonesian Women, The Journey Continues, Canberra: Goanna Print Pby Ltd., 2000

Mulia, Musdah. Toward Marital Law, http/ WWW.Centro.Com

Mulyati, Sri (ed), Relasi Suami Istri Dalam Islam, Jakarta: PSW UIN Jakarta, 2004

Pigeaud, Th, and H. J. de Graaf. "Islamic States in Java." I500-1700', Verhandelingen van Het Koninklijk Instituut Voor Taal, Land-En Volkenkunde 70 (1976).

Pigeaud, Theodore Gauthier. Islamic States in Java 1500-1700. Leiden: Brill, 1976.

Orr, Robert Whyte and Pauline Whyte, the Women in Rural Asia, USA: Westview Press, Inc, 1982

Report of Proceeding on The Regional Workshop, Islam, Reproductive Health and Women's Rights, organized by Sisters in Islam, held in Kuala Lumpur Malaysia at $20^{\text {th }}-23^{\text {rd }}$, August, 1998

Subaharianto, Andang, et all., Tantangan Industrialisasi Madura, Malang: Bayumedia Publishing, 2004 